DOI: https://doi.org/10.24144/2409-6857.2019.1(53).246-251

УДК 336.56:336.225.673

Фоміна О. В., Музичук М. I.

\title{
СУЧАСНІ АСПЕКТИ МІЖНАРОДНОГО РЕГУЛЮВАННЯ ТРАНСФЕРНОГО ЦІНОУТВОРЕННЯ
}

\begin{abstract}
Досліджено основні напрямки міжнародного регулювання контрольованих господарських операцій, вивчено міжнародні нормативні акти, що регулюють трансфертне ціноутворення. Проведено аналіз стану впровадження в Україні міжнародних ініціатив з адміністрування контрольованих операцій. Розкрито поняття автоматичного обміну податковою інформацією та порядку його здійснення. Досліджено аспекти, що стосуються багатосторонньої конвенції MLI. Здійснено аналіз терміну «тест основної цілі» (Principal Purpose Test, PPT).
\end{abstract}

Ключові слова: Трансферна ціна, ОЕСР, автоматичний обмін інформацією, country-by-country report, багатостороння конвенція MLI, тест основної цілі.

Постановка проблеми. Актуальність проблеми обумовлена глобалі-зацією світової економіки, активізації міжнародної торгівлі та вільного переміщення фінансових потоків.

За оцінками Світового банку, близько 2/3 операцій світової торгівлі здійснюється всередині транснаціональних корпорацій, що свідчить про потужність внутрішньофірмових каналів корпорацій та бізнес-груп як каналів переміщення фінансових ресурсів [1].

У більшості країн світу структура податкових систем значною мірою базується на оподаткуванні прибутку. Тому ціноутворення дає широкі можли-вості для розподілу прибутку між залежними організаціямип [2]. Держави втрачають у податкових надходженнях внаслідок використання мультина-ціональними підприємствами агресивного податкового планування для перене-сення доходів до місць (юрисдикцій) iз більш сприятливими режимами опо-даткування [3]. Свідченням посиленої уваги у світі до трансфертного ціно-утворення $€$ врахування практики його регулювання в конкретній країні як одного з 34 критеріїв при складанні Світовим банком рейтингу конкуренто-спроможності національних податкових систем.

За оцінками ОЕСР, втрати бюджетів держав світу від розмивання бази оподаткування i

Фоміна Олена Володимирівна, д.е.н., доцент, завідувач кафедри обліку та оподаткування KHTEУ E-mail: fevfin@gmail.com

Музичук Мар'яна Іванівна, аспірант кафедри кафедри обліку та оподаткування, менеджер 3 податків та зборів центру надання консультаційних послуг (Львівська філія), Товариство 3 обмеженою відповідальністю "Прайсу-отер-хаусКуперс" Львів, Україна, моб. 063-367-03-72 E-mail: Mariana.muzychuk@ukr.net переміщенні прибутків за кордон, щороку сягають \$100-240 млрд. або 4-10\% сукупних надходжень від податку на прибуток підприємств [4].

Питання регулювання трансферного ціноутворення $\epsilon$ актуальним не лише через суттєві сумі податків, а й через його складність, вирішення якого залежить від досконалого розуміння фактів та економічної суті операцій [5].

Аналіз останніх досліджень і публікацій. Питання трансфертного ціноутворення досліджували у своїх працях I. Амеліна [6], Р. Багаутдинов [7], О. Вотчаєв [8], Ю. Зав'ялова [9], Л. А. Задорожна [10], М. Мішин, К. Непесов [11], B. Пашкус [12], Н. Томашевська [13], А. Алєксєєва, І. Ігнатенко, I. Карпенко [14].

Поняття “трансферного ціноутворення" в економічній теорії та практиці сформовано в 1903 році німецьким вченим Е. Шмаленбаха [15].

Питання трансфертного ціноутворення вивчали С.С. Брехов, В.І. Короун, А.А. Заікін, Д.М. Касаткін, О.А. Філонов, О.О. Парфенова та інші, а також такі зарубіжні вчені як А. Вагенгофер, Дж. Дірден, К. Друрі, Р. Ентоні, Г. Кюппер, Д. Пфаф та інші.

Проте, накопичений досвід науковців не розкриває повністю питання облікового забезпечення трансфертного ціноутворення, а наявність різних під-ходів до його розуміння спонукають більш детально дослідити цю проблему.

Формулювання цілей статті: узагальнення міжнародного досвіду 3 трансферного ціноутворення та окреслення шляхів його впровадження в Україні, враховуючи останні тенденції регулювання трансферного ціноутворення.

Опис основного матеріалу дослідження. Особливе значення в механізмі регулювання трансферного ціноутворення має встановлення факту пов'язаності (контролю) сторін. Операції 
між взаємопов'язаними особами автоматично вважаються такими, в яких застосовують механізм трансферного ціноутворення. Отже, вони підлягають особливому контролю на умовах використання принципу “витягнутої руки” [16].

Оподаткування є однім з ключових елементів політики суверенної держави, однак незалежні країни не можуть самостійно прийняти до уваги податкові правила інших країн, і як наслідок виникають прогалини та супереч-ності в регулюванні контрольованих операцій, що в свою чергу створює сприятливі можливості для мінімізації податкових зобов'язань мультинаціональних компаній. Отже, очевидним стає факт, що для успішної боротьби 3 податковими зловживаннями країні повинні об’єднати свої зусилля.

На сьогодні основним міжнародним органом, що здійснює регулювання

трансферного ціноутворення $є$ Організація економічного співробітництва та розвитку (ОЕСР). Діяльність ОЕСР у сфері оподаткування зосереджена навколо наступних напрямів:

- розробка інструкцій 3 застосування двосторонніх Податкових угод;

- розробка інструкцій 3 трансфертного ціноутворення;
- обмін досвідом у сфері обміну інформацією та банківської таємниці;

- вивчення проблем міжнародного ухилення від оподаткування виявлення схем, задіяних у податковому шахрайстві, підготовка відповідних рекомендацій;

- визначення шляхів модернізації податкових систем з метою адаптації до нових глобальних ринків фінансів та капіталу.

3 метою усунення неузгодженостей і прогалин у міжнародному податковому законодавстві ОЕСР розпочала низку ініціатив, найсуттєвішою 3 яких $є$ План дій для боротьби 3 розмиванням бази оподаткування і переміщенням прибутків за кордон (План BEPS ), який передбачає 15 дій для усунення прогалин у міжнародному податковому регулюванні, що уможливлюють «приховування» корпоративного прибутку та його штучне переміщення у низькоподаткові юрисдикції, де компанії не здійснюють економічної діяльності.

Мінімальний стандарт Плану дії BEPS включає чотири кроки, які є обов'язковими до виконання. Україна взяла на себе зобов'язання імплементувати обов'язкові чотири заходи Плану дії BEPS Перелік дій, що містяться у Плані BEPS наведено у таблиці 1.

Табличя 1

Перелік дій Плану ВЕРS від ОЕСР*

\begin{tabular}{|l|l|}
\hline Крок & \multicolumn{1}{|c|}{ Зміст } \\
\hline 1. & Податкові виклики цифрової економіки \\
\hline 2. & Нейтралізація наслідків гібридних податкових схем \\
\hline 3. & Розробка ефективних правил контрольованих іноземних компаній (КІК) \\
\hline 4. & $\begin{array}{l}\text { Обмеження розмивання податкової бази через включення процентних відрахувань та інших } \\
\text { фінансових платежів між пов’язаними особами до складу витрат }\end{array}$ \\
\hline 5. & $\begin{array}{l}\text { Протидія шкідливим податковим практикам більш ефективно, враховуючи принципи прозорості та } \\
\text { сутності }\end{array}$ \\
\hline 6. & Запобігання зловживанням при застосуванні податкових конвенцій \\
\hline & (угод про уникнення подвійного оподаткування) у невідповідних обставинах \\
\hline 7. & Запобігання штучному уникненню статусу постійного представництва \\
\hline $8-10$. & Узгодження результатів трансфертного ціноутворення із створенням вартості: \\
\cline { 2 - 3 } в частині нематеріальних активи, ризики і капітал, інші операції високого ризику \\
\hline 11. & Вимірювання та моніторинг виконання плану ВЕРS \\
\hline 12. & Правила розкриття інформації про схеми агресивного податкового планування \\
\hline 13. & $\begin{array}{l}\text { Документація з трансфертного ціноутворення та звітування у розрізі країн (від англ. Соиntrу-bу- } \\
\text { Соипту Rерогтіn, СьСR) }\end{array}$ \\
\hline 14. & Підвищення ефективності механізмів урегулювання податкових спорів \\
\hline 15. & $\begin{array}{l}\text { Розробка багатостороннього документа для внесення змін у двосторонні податкові угоди про } \\
\text { уникнення подвійного оподаткування }\end{array}$ \\
\hline
\end{tabular}

*Джерело: BEPS Actions by OECD [17].

Примітка: виділеним позначено чотири заходи, які включені до мінімального стандарту впровадження Плану BEPS.

Транснаціональні компанії намагаються зменшити податки як в країні де ними отримується дохід, так і в країні компаній, які ними контролюються і якій у них виникає джерело доходу. 3 цією метою компанії організовують перена-правлення доходу із податкових юрисдикцій, де він виникає, в треті юрисдикції (проміжні/транзитні) 
накопичення прибутку до його розподілення в країну контролера. Такими третіми країнами зазвичай $є$ країни зі сприятливим подат-ковим режимом (в тому числі офшорні юрисдикції).

Правила КІК були розроблені для ситуацій, в яких контрольована іноземна компанія (КIK) отримує і накопичує прибуток, не розподіляючи його довгий час на користь особи (юридичної чи фізичної), якою вона контролюється, внаслідок чого відбувається відстрочення оподаткування доходу у країні контролера. Водночас неоподаткування самої КІК у країні їі реєстрації досягається завдяки тому, що вона розміщена у юрисдикції зі сприятливим податковим режимом. В міжнародній практиці правила КІК передбачають включення в оподатковувану базу контролера (компанії-резидента або фізичної особи-резидента) прибутку КІК. Тобто механізм КІК передбачає, що прибуток іноземної компанії (прибуток КІК) включається в оподатковувану базу юридичної особи або фізичної особи, яка іiі контролює. Таким чином, правила КІК фактично передбачають включення прибутку КІК до оподаткованого прибутку іiі материнської компанії, незалежно від того чи розподіляє контрольована компанія дивіденди на їх користь.

Застосування правил КІК здійснюється тоді, коли виникає штучне перенесення оподатковуваного прибутку в юрисдикції іноземних компаній, а саме:

- резидент однієї держави контролює іноземну компанію шляхом істотної участі в ऑii капіталі або іншим чином;

- дохід КІК є пасивним;

- дохід КІК в країні ¥ї резиденства не оподатковується

- дохід КІК в країні іiі резиденства оподатковується за низькою ставкою.

Шостим кроком дії Плану дій BEPS, який входить до чотирьох мінімальних, передбачено забезпечення мінімального рівня захисту від практики пошуку найвигіднішої угоди. Для цього передбачено доповнення угоди про уникнення подвійного оподаткування правилом основної мети/тест основної цілі (Principal Purpose Test, PРТ). Даний тест передбачає аналіз мети, при застосуванні угоди про уникнення подвійного оподаткування суб'єктами господарювання. Відповідно, платники податків не можуть користуватися вигодами, передбаченими положеннями угоди про уникнення подвійного оподаткування, якщо застосування таких положень було однією 3 основних цілей укладеного між ними господарського договору. Таким чином, застосування преференцій угоди про уникнення подвійного оподаткування не може являтися основною цілю, які контрагенти переслідують у своїй діяльності.

Новий стандарт 3 автоматичного обміну фінансовою інформацією в податкових цілях був розроблений ОЕСР у співпраці з G20 у 2014 році. За своєю природою, автоматичний обмін інформацією - це передача інформації про нерезидентів, яка надсилається юрисдикцією, де знаходяться доходи або активи таких нерезидентів, до юрисдикції, в якій такий нерезидент $є$ платником подат-ків. Відповідно до положень даного стандарту усі фінансові установи без вийнятку повинні збирати інформацію про рахунки нерезидентів. Під фінансови-ми інститутами також розуміються не лише банківські установи, але й брокер-ські, страхові компанії тощо.

Однім 3 ключових моментів нової всесвітньої податкової парадигми $\epsilon$ вимога подання платниками CbCR - country-by-country report, передбаченого кроком 13 плану BEPS. CbCR $\epsilon$ формою звітності, що повинна містити дані про отриманий дохід (як від пов'язаних, так i непов'язаних осіб), прибуток, суми нарахованих податкових зобов'язань, суми сплаченого податку на прибуток, кількість найманих працівників, матеріальні та нематеріальні активи щодо кожної податкової юрисдикції в якій компанія проводить свою діяльність. Окрім того, форма звітності має розкривати інформацію про кожну структурну одини-цю в складі транснаціональної компаніі, ii податкову юрисдикцію та конкретний вид діяльності.

Згідно вимог ОЕСР country-by-country report має подаватися транснаціо-нальними компаніями, чий сукупній становить 750 мільйонів євро та більше. Завдяки такій звітності податкові органи зможуть здійснити аналіз ризиків трансферного ціноутворення та здійснювати обмін податковою інформацією між податковими органами всіх юрисдикцій, в яких здійснюють свою діяльність транснаціональні компанії. Обмін має відбуватися на постійній основі, щорічно в автоматичному режимі. Тобто, податкові органи повинні раз на рік отримуватимуть інформацію щодо руху на банківських рахунках кожного окремого платника податків, незалежно від того в якій юрисдикції він відкритий, та щодо всіх його доходів та витрат.

Автоматичний обмін інформацією впроваджено в країнах ЄС у 2017 році, а у 2018 ще 51 країна приєдналася до системи обміну інформацією, серед них Австрія, Австралія, Барбадос, Бразилія, Канада, Китай, Монако, Кувейт, Ізраїль, Індонезія, Туреччина, 
Швейцарія. Станом на кінець січня 2019 року 76 країн вже впровадили автоматичний обмін інформацією [18]. В той же час, на даному етапі в Україні автоматичний обмін інформацією досі не впроваджено, що обумовлено необхідністю здійснити придбання програмного забезпечення та навчання відповідальних співробітників фінансових інститутів та Держаної Фіскальної Служби. Наступним етапом підготовки України буде перевірка 3 боку ОЕСР на предмет дотримання вимог стандарту 3 автоматичного обміну інформацією.

Третім важливим напрямком для ОЕСР виступає цифрова економіка. Капіталізація даного ринку щорічно стрімко зростає. В той же час, дані операції уникають оподаткування, їх неможливо відслідкувати та виміряти. Ці операції становлять потенційну загрозу для світової економіки, натомість вони одночасно виступають економічним стимулом у випадку коли дані потоки будуть оподатковані. У ОЕСР створена робоча група по Digital Economy, котра працює над тим, щоб розробити та врегулювати єдині стандарти, за допомогою яких стане можливо поперше, бачити ці операції, по-друге, оподатковувати їх. До 2020 року ОЕСР планують закінчити розробку стандарту, який, очевидно, потім стане обов'язковим для втілення в країнах $\epsilon C$, i в таких країнах, як Україна, яка підписала Угоду про Асоціацію з СС.

Кроком 15 Плану дій BEPS (i четвертим мінімальним) $\epsilon$ підписання країноюучасницею багатосторонньої конвенцію, яка $є$ важливим кроком для протидії розмиванню бази оподаткування та виведення прибутку 3-під оподаткування. Багатостороння конвенція MLI це угода, приєднавшись до якої, країна отримує можливість одночасного внесення змін в усі або деякі діючі Конвенції про уникнення подвійного оподаткування. Україна стала 83-ю юрисдикцією, котра приєдналася до Конвенції, яка в даний час охоплює більше 1400 двосторонніх податкових угод. Після підписання Конвенції MLI, Україна отримає змогу одночасного внесення змін до всіх або деяких чинних Конвенцій про уникнення подвійного оподаткування. Таким чином, Україна зробила важливий крок в рамках Плану дій щодо боротьби 3 розмиванням бази оподаткування i виведенням прибутку 3-під оподаткування (План дій BEPS). Підписання Конвенції означає:

-посилення боротьби 3 агресивним податковим плануванням;

-гармонізація міжнародних податкових правил;

-забезпечення більш прозорого податкового середовища, що покращить інвестиційний клімат, сприятиме зростанню економіки та стимулюванню міжнародної торгівлі.

Однак для впровадження в дію положень даної Конвенції має бути здійснена ії ратифікація.

$\begin{array}{ccc}\begin{array}{c}\text { Висновки } \\ \text { досліджень. }\end{array} & \begin{array}{l}\text { перспективи } \\ \text { Практика }\end{array} & \begin{array}{c}\text { подальших } \\ \text { здійснення }\end{array}\end{array}$
мультинаціональними компаніями заниження бази оподаткування при внутрішньогосподарських операціях та використання низькоподаткових юрисдикцій стали причиною об'єднання міжнародної спільноти 3 метою протидії мінімізації оподаткування. Зважаючи на специфіку національного регулювання, при адмініструванні трансферного ціноутворення важливу роль мають правила, встановлені нормативними актами, що прийняті на міжнародному рівні.

На сьогодні податкове законодавство України в сфері трансферного ціноутворення не адаптовано до останніх ініціатив, згідно яких вже здійснюється регулювання контрольованих операцій у більш ніж 70 країн світу. Для уникнення відтоку капіталу 3 країни та підвищення рівня податкових надходжень України вкрай важливо якомога скоріше впровадити ініціативи, передбачені Планом BEPS.

Перспективним напрямком подальшого дослідження є: аналіз упорядкування та надання пояснень за правилами ТЦ податковими органами різних країн; узгодження ними загальних вимог щодо документації про контрольовані операції; практична реалізація автоматичного обміну інформацією та її вплив на оподаткування контрольованих операцій; впровадження та поширення механізму договору про попереднє узгодження в рамках трансферного ціноутворення ( Advance pricing arrangement).

\section{СПИСОК ВИКОРИСТАНИХ ДЖЕРЕЛ}

1. Transfer Pricing Technical Assistance. Global Tax Simplification Program / Presentation given by Rajul Awasthi. Brussels, 24 February 2011. [Електронний ресурс]. - Режим доступу: http://www.taxcompact.net/documents/WBIFC-TP-RA-ITC-EU-event_Feb-2011.pdf

2. Алєксєєва А. Трансфертне ціноутворення як механізм податкового контролю / А. Алєксєєва, Т. Ігнатенко // Вісник КНТЕУ. - 2014. - № 3. - С. 85-95. 
3. Мішин М., Курілов С. Світовий досвід трансфертного ціноутворення: тенденції та перспективи // Вісник. Офіційно про податки. - № 38, 2013. - [Електронний ресурс]. - Режим доступу: http://www.visnuk.com.ua/ua/pubs/id/6064.

4. План дій BEPS: Україна унеможливлює податкові лазівки // Вісник. Офіційно про податки. - № 42, 2018. [Електронний ресурс]. - Режим доступу: http://www.visnuk.com.ua/uk/publication/100009744-plan-diy-bepsukrayina-unemozhlivlyuye-podatkovi-lazivki?issue $=5679$.

5. Ефективне вирішення викликів трансферного ціноутворення. Dealing Effectively with the Challenges of Transfer Pricing. - [Електронний ресурс]. -Режим доступу: http://www.oecd.org/site/ctpfta/49428070.pdf.

6. Амеліна І.В. Міжнародні економічні відносини / І.В. Амеліна, Т.Л. Попова, С.В. Владимиров. - К.: Центр учбової літератури, 2013. - 256 с

7. Багаутдинов Р.И. Исторические аспекты развития трансфертного ценообразования / Р.И. Багаутдинов, Л.Ф. Султанова // Экономика и современный менеджмент: теория и практика: сборник статей по материалам XXXI Международной научно-практической конференции. - Новосибирск: СибАК, 2013. - № 11 (31). - 228 с.

8. Вотчаев А.А. Влияние налогов на цены: политика регулирования и контроля: автореф. дисс. . канд. эконом. наук: спец. 08.00.10 / А.А. Вотчаев. - Саратов, 2009. - 21 с

9. Завьялова Ю.Н. Трансфертное ценообразование: объект уничтожения или насущная потребность? / Ю.Н. Завьялова, И.В. Хаменушко // Налоговед. - 2005. - № 4. - [Электронный ресурс]. - Режим доступа: http://nalogoved.ru/art/176.

10.Задорожная А.И. История института налогового регулирования трансфертного ценообразования / А.И. Задорожная // Петербургский юрист. - 2014. - № 3. - С. 146-165.

11.Непесов К.А. Налоговые аспекты трансфертного ценообразования: сравнительный анализ опыта России и зарубежных стран / К.А. Непесов. - М.: Волтерс Клувер, 2007. - 233 с.

12.Пашкус В.Ю. Теория трансфертного ценообразования в современной организации: понятия, модели, проблемы / В.Ю. Пашкус // [Электронный ресурс]. - Режим доступа: http://www.ippnou.ru/ aгiic1 $\mathrm{e}^{\wedge} \mathrm{p}$ ?Mailic1 $=000761$

13.Томашевская Н. Ценовая позиция / Н. Томашевская // [Электронный ресурс]. - Режим доступа: http://www.integrites.com/ru/publication/902/http:/o3A//www.integrites.com.

14.Карпенко І.В. Методика обліку трансфертного ціноутворення на підприємствах торгівлі / Карпенко І.В. // Науковий вісник Ужгородського університету. - 2018. - № 1. - С. 416-424.

15.Schmalenbach E. ÜberVerrechnungspreise / E. Schmalenbach // Zeitschriftfürhandelswissenschaftliche Forschung. 1909. - Vol. 3. - № 3. - 165-185.

16.Зирянова О. Л. Регулювання трансфертного ціноутворення: міжнародний досвід та українська практика / О. Л. Зирянова // Вісник Інституту економіки та прогнозування. - 2013. - С. 77-80. - Режим доступу: http://nbuv.gov.ua/UJRN/viep_2013_13_15

17.Офіційний сайт ОЕСР [Електронний ресурс]. - Режим доступу: http://www.oecd.org/tax/beps/beps-actions.htm. 18.Офіційний сайт ОЕСР [Електронний ресурс]. - Режим доступу: http://www.oecd.org/ctp/exchange-of-taxinformation/CbC-MCAA-Signatories.pdf.

\section{REFERENCES}

1. Transfer Pricing Technical Assistance. Global Tax Simplification Program. (2011). Presentation given by Rajul Awasthi. taxcompact.net. Retrieved from: http://www.taxcompact.net/documents/WB-IFC-TP-RA-ITC-EU-event_Feb2011.pdf [in English].

2. Alyeksyeyeva, A. (2014). Transfertne tsinoutvorennya yak mekhanizm podatkovoho kontrolyu [Transfer pricing as a mechanism of tax control]. Visnyk KNTEU - Bulletin of KNTEU, 3, 85-95 [in Ukrainian].

3. Mishyn, M., \& Kurilov, Ye. (2013). Svitovyy dosvid transfertnoho tsinoutvorennya: tendentsiyi ta perspektyvy [World experience of transfer pricing: trends and perspectives]. Visnyk. Ofitsiyno pro podatky - Bulletin. Officially about taxes, 38. visnuk.com.ua. Retrieved from: http://www.visnuk.com.ua/ua/pubs/id/6064. [in Ukrainian].

4. Plan diy BEPS: Ukrayina unemozhlyvlyuye podatkovi lazivky [BEPS action plan: Ukraine makes tax loopholes impossible] (2018). Visnyk. Ofitsiyno pro podatky - Bulletin. Officially about taxes, 42 2018. visnuk.com.ua. Retrieved from: http://www.visnuk.com.ua/uk/publication/100009744-plan-diy-beps-ukrayina-unemozhlivlyuye-podatkovilazivki?issue $=5679$. [in Ukrainian].

5. Dealing effectively with the challenges of transfer pricing. (n.d.). www.oecd.org. Retrieved from: http://www.oecd.org/site/ctpfta/49428070.pdf. [in English].

6. Amelina, I.V. (2013). Mizhnarodni ekonomichni vidnosyny [International economic relations]. K.: Tsentr uchbovoyi literatury [in Ukrainian].

7. Bahautdynov, R.I. (2013). Istorycheskye aspekty razvitiya transfertnoho tsenoobrazovaniya [Historical aspects of the development of transfer pricing]. Proceedings from: Ekonomika i sovremennyy menedzhment: teoriya y praktika: sbornyk statey po materyalam XXXI Mezhdunarodnoy nauchno-praktycheskoy konferentsyy - Economics and modern management: theory and practice: a collection of articles on the materials of the XXXI International Scientific and Practical Conference., 11 (31). Novosybyrsk: SybAK [in Russian]. 
8. Votchaev, A.A. (2009). Vliyanye nalogov na tseny: politika regulirovaniya i kontrolya [Impact of taxes on prices: policy of regulation and control]. Extended abstract of candidate's thesis. Saratov [in Russian].

9. Zavyalova, Yu.N. (2005). Transfertnoe tsenoobrazovanye: obekt uniychtozheniya ili nasushchnaya potrebnost'? [Transfer pricing: destruction object or urgent need?] Nalohoved - Tax officer, 4. nalogoved.ru. Retrieved from: http://nalogoved.ru/art/176. [in Russian].

10.Zadorozhnaya, A.I. (2014). Istoriya instituta nalogovoho regulirovaniya transfertnogo tsenoobrazovaniya [The history of the institute of tax regulation of transfer pricing] Peterburhskyy yuryst - Petersburg lawyer, 3, 146-165 [in Russian].

11.Nepesov, K.A. (2007). Nalohovye aspekty transfertnogo tsenoobrazovaniya: sravnitel'nyy analyz opyta Rossii i zarubezhnykh stran [Tax aspects of transfer pricing: a comparative analysis of the experience of Russia and foreign countries]. M.: Volters Kluver [in Russian].

12.Pashkus, V.Yu. (n.d.). Teoriya transfertnogo tsenoobrazovaniya v sovremennoy organyzatsyi: ponyatiya, modeli, problemy [Theory of transfer pricing in modern organization: concepts, models, problems]. ippnou.ru. Retrieved from: http://www.ippnou.ru/ ahi-is1 $\mathrm{e}^{\wedge} \mathrm{r}$ ?Mai1is1e=000761 [in Russian].

13.Tomashevskaya, N. (n.d.). Tsenovaya pozitsyya [Price position]. integrites.com. Retrieved from: http://www.integrites.com/ru/publication/902/http:/o3A//www.integrites.com [in Russian].

14.Karpenko, I.V. (2018). Metodyka obliku transfertnoho tsinoutvorennya na pidpryyemstvakh torhivli [Methodology of the transfer portfolio in the trading enterprises]. Naukovyy visnyk Uzhhorods'koho universytetu - Scientific Bulletin of Uzhgorod University, 1, 416-424 [in Ukrainian].

15.Schmalenbach, E. (1909). Über Verrechnungspreise [About transfer prices]. Zeitschrift für handelswissenschaftliche Forschung - Journal of Commercial Studies, 3, 165-185 [in German].

16.Zyryanova, O.L. (2013). Rehulyuvannya transfertnoho tsinoutvorennya: mizhnarodnyy dosvid ta ukrayins'ka praktyka [Transfer pricing regulation: international experience and Ukrainian practice]. Visnyk Instytutu ekonomiky ta prohnozuvannya - Bulletin of the Institute of Economics and Forecasting, 77-80. nbuv.gov.ua. Retrieved from: http://nbuv.gov.ua/UJRN/viep_2013_13_15 [in Ukrainian].

17.Ofitsiynyy sayt OESR [Official site of OECD]. oecd.org. Retrieved from: http://www.oecd.org/tax/beps/bepsactions.htm. [in English].

18.Ofitsiynyy sayt OESR [Official site of OECD]. oecd.org. Retrieved from: http://www.oecd.org/ctp/exchange-of-taxinformation/CbC-MCAA-Signatories.pdf. [in English].

Одержано 04.03.2019 